腸閉塞, 腹膜炎にて発症し, 緊急手術を施行した好酸球性腸炎の 1 例

\author{
東川口病院外科・胃腸科 \\ 吉 岡 輝 史 根岸 通
}

\begin{abstract}
症例は46歳, 男性. 腹痛, 嘔吐を主訴に当院受診. 腹部は膨満し, 右下腹部に圧痛, 反兆痛, および筋性防御を認めた。腹部単純 X線写真では小腸ガス像が著明であり, 二 ボー形成もみられた，急性虫垂炎による腸閉塞, 腹膜炎を疑い緊急手術を施行した。腹 腔内に黄色透明の腹水を中等量認めたが, 虫垂には軽度の炎症所見がみられるのみであ った。腹腔内を検索すると, 回盲部より約 $130 \mathrm{~cm}$ 口側の回腸に硬結を認めた。硬結部分 より口側の回腸は拡張しており，この部分の腸管内腔が狭くなり腸閉塞をおこしたと考 えられた。硬結部分を含めた回腸部分切除術を施行した。術後, 摘出検体を開くと, 粘 膜が発赤, 肥厚していた。病理所見では, 硬結部分の全層にわたり好酸球を主体とする 炎症性細胞の浸潤を認め，好酸球性腸炎と診断された。
\end{abstract}

索引用語：好酸球性腸炎, イレウス, 腸切除

\section{はじめに}

好酸球性腸炎は稀な疾患であり, 緊急手術を施行し

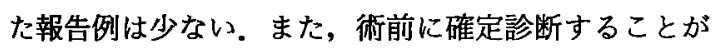
困難な疾患とされている，今回，腸閉塞，腹膜炎にて 緊急手術を施行し, 病理組織検査にて診断できた好酸 球性腸炎の 1 例を経験したので報告する。

\section{症 例}

患者：46歳, 男性.

主訴: 腹痛, 嘔吐.

既往歴・家族歴：特記すべきことなし.

現病歴：2000年 5 月 18 日深夜 2 時頃に笑, 腹痛, 嘔吐が出現. その後, 徐々に症状悪化したため同日朝, 当院外来を受診した.

現症: 身長 $167.5 \mathrm{~cm}$, 体重 $62.2 \mathrm{~kg}$, 体温 $37.1^{\circ} \mathrm{C}$, 血 圧 $138 / 80 \mathrm{mmHg}$, 脈拍 $60 /$ 分・整, 眼球・眼瞼結膜に黄 染わよび筫血なし. 腹部膨満, 右下腹部に圧痛, 反兆 痛, 筋性防御を認めた。

血液検查所見 : 白血球 $19,500 / \mu 1$ と上昇（好酸球 1 \%).CRP0.2mg/dl, その他の血液生化学所見に異常は 認めなかった。

腹部単純 X線所見：小腸ガス像およびニボー形成を

2000 年 7 月 7 日受付 2000 年 8 月 3 日採用

〈所属施設住所〉

テ333-0801 川口市東川口 $2-10-8$
認めた（図 1 )。

以上より, 急性虫垂炎による腸閉塞, 腹膜炎を疑い 緊急手術を施行した。

手術所見 : 腹直筋旁切開法にて開腹. 腹腔内に黄色 透明の腹水を中等量認めたが, 虫垂には軽度の炎症所 見がみられるのみであった，他の原因を考え，腹腔内 を検索すると, 回腸末端より約 $130 \mathrm{~cm}$ 口側の回腸に硬 結を認め(図 $2 \mathrm{a}, \mathrm{b}$ ), 周囲の奬膜面は炎症により軽 度発赤していた。硬結部分より口側の回腸は拡張して おり，この部分の腸管内腔が狭くなり腸閉塞を抗こし たと考えられた。また，一部の小腸間膜リンパ節が腫 脹していた．硬結部分を含めた回腸約 $20 \mathrm{~cm}$ を切除す ることとして, 回腸部分切除術, 虫垂切除術, 小腸間 膜リンパ節生検を施行した。

切除標本肉眼所見：硬結部分の粘膜は発赤, 肥厚し ていた（図3).

病理組織学的所見：硬結部分の全層にわたり好酸球 を主体とする炎症性細胞の浸潤を認めた（図 4). 生検 したリンパ節に炎症所見および好酸球浸潤を認め, 腹 水中にも好酸球を認めた。虫垂に好酸球浸潤は認めな かった.

術後経過: 血液中 $\mathrm{IgE}$ 值測定, $122 \mathrm{IU} / \mathrm{ml}$ と正常範 囲内であった（正常值：200IU/ml 以下)。さらに上部 消化管内視鏡検査を施行. 組織生検を数力所上り行っ たところ, 胃幽門部, 十二指腸球部および下行脚に好 


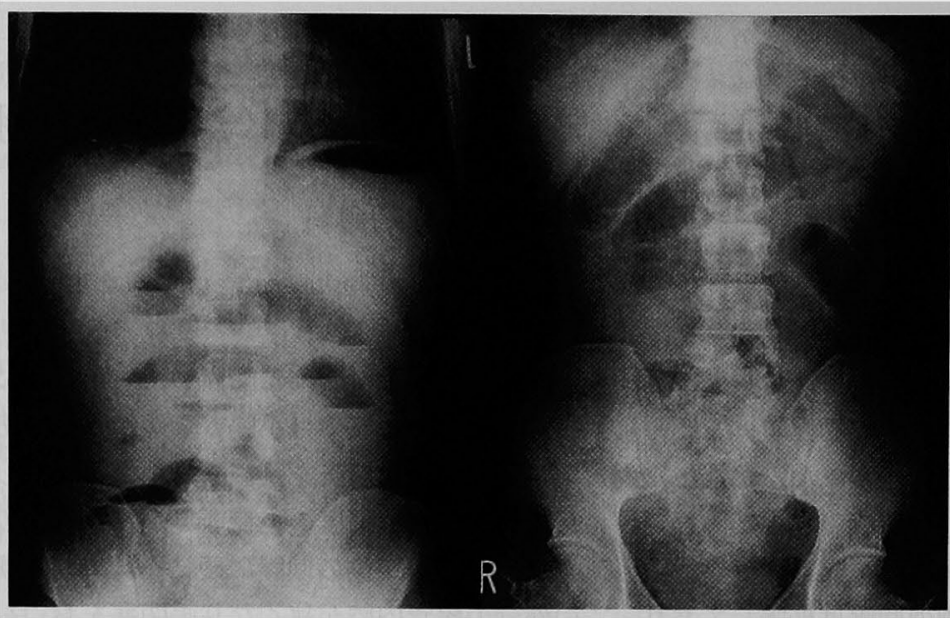

図 1 腹部単純 $\mathrm{X}$ 線写真（左：立位，右：臥位）：小腸ガス像扔よびニボー形 成を諗めた。
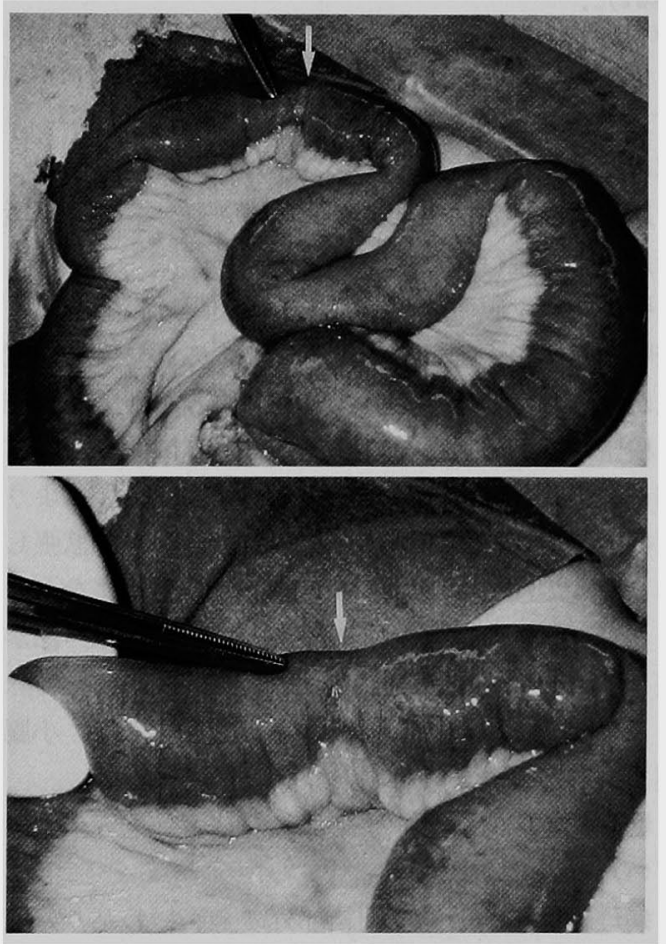

肛門側

口側

図 $2 \mathrm{a}, \mathrm{b}$ 手術所見：回盲部より約 $130 \mathrm{~cm}$ 口側の 回腸に硬結 (矢印) を認め，周囲の墏膜面は炎症に より軽度発赤していた。

$\frac{\mathrm{a}}{\mathrm{b}}$

酸球浸潤を認めた。順調に経過し第30病日に退院した。 外来にて経過観察を続けているが異常症状はみられ

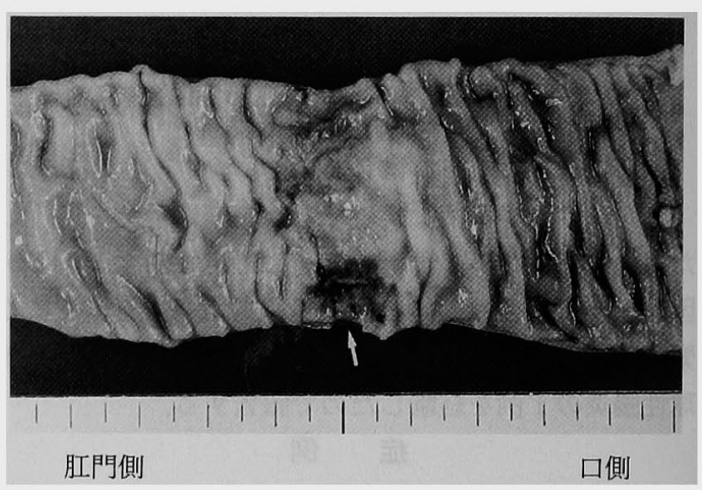

図 3 切除標本：硬結部分の粘膜は発赤, 肥厚していた (矢印).

ず、現在，ステロイド治療などは行っていない. 考 察

好酸球性胃腸炎は稀な疾患であり，1937年 Kaijser ${ }^{1)}$ によりはじめて報告された。特徴として消化管壁への 好酸球漫潤および組織浮腫をきたし, 胃・小腸に好発 するといわれている.

診断基準として Greenberger ら²)は（1)胃あるいは 腸管壁への好酸球浸潤，(2)末梢血中好酸球増多，(3)特 定食物摄取後の症状出現の 3 項目をあげているが，必 ずしもすべての項目を满たす必要はなぐ，すべてを 満たす症例はほとんどみられていない，消化管への好 酸球浸潤にて診断されているのが現状である.

病因としてアレルギー, 免疫学的異常の関与などが 


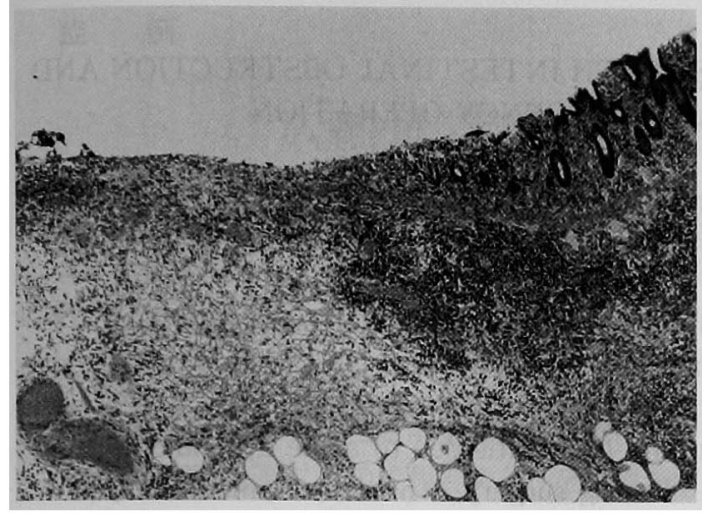

图 4 病理組織学所見：好酸球を主体とする炎症性細胞 の浸潤を認めた（HE 染色， $\times 10 ）$ 。

考えられている4が, アレルギー歴, 血液中 $\operatorname{IgE}$ 值の上 昇, 特定食物捸取などが認められない症例も多く, い まだに明らかではない. 本症例においてもアレルギー 歴岋なく，入院中の血液中 $\operatorname{IgE}$ 值は正常であり，食物 揁取などからも病因は明らかにできなかった。

臨床症状は腹痛, 嘔気, 嘔吐, 下痢, 腹部膨満感, 食欲不振など様々である. Klein ら"は，消化管壁への 好酸球浸潤を部位別に, (1) predominant mucosal disease (粘膜浸潤型), (2) predominant muscle layer disease (筋層浸潤型), (3) predominant subserosal layer disease（漿膜浸潤型）の 3 つに分類し，その部 位により臨床症状, 所見は異なると報告している。し かし，これらにあてはまらない症例も散見される。西 村ら ${ }^{61}$ は消化管壁全層に好酸球浸潤がみられる症例 は, 多彩な臨床症状を呈し, 末梢血好酸球増多を示す ことが低い傾向から transmural disease という概念 で報告している，本症例は硬結部分の腸管壁全層にわ たり好酸球が浸潤し，末梢血好酸球增多は認めず，こ の概念に該当すると考えられる。

治療はステロイド投与が著効する778) とされ，症状に 応じた対症療法による保存的治療が第一選択とな る ${ }^{9}$.一般的に予後は良好であるが再発を繰り返し，長 期にわたる例も多い8100. 外科的治療は腸閉塞例や穿 孔例に行われる．また外科的治療を施行した症例は消 化管壁全層にわたり好酸球が浸潤している傾向が多 い11).本邦における好酸球性胃腸炎の手術報告例は,調 べ得られた限りでは，胃：9例，小腸：21例（自験例 を含む), 大腸：1 例の計31例であった。このうち術前 診断されている症例は少ない，病変部分が小腸の場合
には組織生検は困難であり，腸閉塞，虫垂炎との診断 で手術に至っている例が多い6). 特に本症例のように 急激に発症, 進展し, 末梢血中の好酸球が増加しない 例では術前に確定診断をすることは極めて困難であ る.

原因不明の腹痛，下痢などの消化器症状をきたす病 態や原因不明の腸閉塞例および穿孔例では本疾患を考 慮して精查, 治療を進めるべきであると思われた。

\section{結 語}

腸閉塞, 腹膜炎にて緊急手術を施行し, 病理組織検 査にて診断できた好酸球性腸炎の 1 例を経験した。

文献

1) Kaijser $R$ : Zur Kenntnis der allergischen Affektionen des Verdauungskanals vom Standpunkt des Chirurgen aus. Arch Klin Chir $188: 36-$ 64,1937

2) Greenberger N, Gryboski JE : Allergic disorders of the intestine and eosinophilic gas. troenteritis. Gastrointestinal Disease. WB Saunders Co, Philadelphia, 1973, p1063-1082

3) Caldwell JH, Mekhjian HS, Hurtubise PE, et al: Eosinophilic gastroenteritis with obstraction. Gastroenterology $74: 825-828,1978$

4) Miyamoto $T$, Shibata $T$, Matsuura $S$, et al: Eosinophilic Gastroenteritis with Ileus and ascites. Intern Med 35 : 779-782, 1996

5) Klein NC, Hargrore RL, Sleisenger MH, et al: Eosinophilic gastroenteritis. Medicine 49 : 299 $-319,1970$

6）西村 浩，大浦元孝，富田啠男：好酸球性腸炎の 1 例および本邦報告60例の対献的考察. Gastroenterol Endosc $31: 2196-2205,1989$

7）朝倉 均, 三浦総一郎, 浜田慶城他：好酸球性腸 炎. 今日の治療 $3: 33-39,1985$

8) 内藤明広, 川原勝彦, 岩田 宏他: 穿孔性腹膜炎 を繰り返した好酸球性腸炎の 1 例. 日臨外会誌 $59: 2318-2322,1998$

9）浅木 茂：好酸球性腸炎一その診断と治療一. 綜 合臨 $44: 1885-1886,1995$

10）三富弘之，一原 亮，鈴木 裕他：再発をくり返 した好酸球性腸炎の 1 例. Gastroenterol Endosc $29: 1226-1231,1987$

11）小森康司, 松浦 豊, 河野 弘他：好酸球性腸炎 の 1 例。日臨外会誌 $59: 1015-1019,1998$ 


\title{
A CASE OF EOSINOPHILIC ENTERITIS PRESENTED WITH INTESTINAL OBSTRUCTION AND PERITONITIS WHICH REQUIRED AN EMERGENCY OPERATION
}

\author{
Terufumi YOSHIOKA and Toru NEGISHI
}

Department of Surgery and Gastroenterology, Higashi-Kawaguchi Hospital

\begin{abstract}
A 46-year-old man was admitted to the hospital because of abdominal pain and vomiting. The abdomen was distended. There were tenderness, rebound tenderness, and muscle guarding in the right lower quadrant of the abdomen. Simple abdominal $\mathrm{x}$-ray film revealed prominent gas and niveau formation of the small intestine. Intestinal obstruction and peritonitis due to acute appendicitis were suspected, and an emergency operation was performed. During surgery, a moderate amount of yellow transparent ascites was present in the abdominal cavity, but only mild inflammatory findings were seen in the appendix. An exploration of the abdominal cavity revealed an induration in the ileum about $130 \mathrm{~cm}$ to the ileum end. An oral portion of the ileum from the induration dilated and the narrowed intestinal lumen at the site might cause intestinal obstruction. A partial resection of the ileum including the induration was performed. After the operation when the resected material was opened, redness and thickening of the mucosa were seen. Pathologically transmural infiltration of inflammatory cells mainly composed of eosinophilic leukocytes at the induration was confirmed. Eosinophilic enteritis was diagnosed.
\end{abstract}

